\title{
Mikrobiyal gübre ve vermikompost uygulamalarının baş salata (Lactuca sativa L. var capitata) yetiştiriciliğinde bitki gelişimi, verim ve nitrat içeriğine etkisi
}

\author{
Effect of microbial fertilizer and vermicompost applications on plant growth, yield \\ and nitrate content of head lettuce (Lactuca sativa L. var capitata)
}

\author{
Hakan ALTUNLUE \\ Muğla Sıtkı Koçman Üniversitesi, Ortaca Meslek Yüksekokulu, 48600, Muğla \\ Sorumlu yazar (Corresponding author): H. Altunlu, e-posta (e-mail): haltunlu@gmail.com
}

\section{MAKALE BİLGİSI}

Alınıș tarihi 28 Eylül 2020

Düzeltilme tarihi 20 Ocak 2021

Kabul tarihi 01 Şubat 2021

\section{Anahtar Kelimeler:}

Vermikompost

Mikrobiyal gübreleme

Baş salata

Verim

Nitrat birikimi

\begin{abstract}
ÖZ
Bu çalıșmada toprağa vermikompost ve mikrobiyal gübre uygulamalarının baș salata (Lactuca sativa L. var capitata cv Bombola ) yetiştiriciliğinde bitki gelişimi, verim ve kalitesi üzerine etkilerinin araştırılması amaçlanmıştır. PE sera koşullarına yapılan çalışmada parsel büyüklüğü $20 \mathrm{~m}^{2}$ olup, bir adet kimyasal gübreleme (KG) ile 4 farklı vermikompost $(0,100$, 200 ve $400 \mathrm{~kg} \mathrm{da}^{-1}$ ) ve 2 farklı dozda ticari mikrobiyal gübre (M- ve $\mathrm{M}+$ ) dozu 3 tekerrürlü olmak üzere tesadüf blokları deneme desenine göre uygulanmıștır. Mikrobiyal gübre uygulaması tohuma uygulama ve dikim sonrası olarak iki defada yapılmıştır. Hasat edilen bitkilerde verim, bitki gelişimi ve kalitesini belirlemek için, ortalama baş ağırlı̆̆ $\left(\mathrm{g} \mathrm{bitki}^{-1}\right)$, toplam verim $\left(\mathrm{kg} \mathrm{m}^{-2}\right)$, baş boyu $(\mathrm{cm})$, baş çapı $(\mathrm{cm})$, baş yaş ağırlığ $1(\mathrm{~g})$, baş kuru ağırlı̆̆ $1(\mathrm{~g})$, yaprak rengi (L, a, b, croma, hue), $\mathrm{pH}$, suda çözünebilir kuru madde (SÇKM) (\%), askorbik asit (Vitamin C) miktarı (mg $\left.100 \mathrm{~g}^{-1}\right)$ ve nitrat içeriği $\left(\mathrm{mg} \mathrm{kg}^{-1}\right)$ ölçülmüștür. Deneme sonuçlarına göre, $400 \mathrm{~kg} \mathrm{da}^{-1}$ vermikompost ve mikrobiyal gübre uygulamasının kimyasal gübreleme ile aynı şekilde bitki gelişimi oluşturduğu ve elde edilen bitkilerin renk ve diğer kalite kriterleri bakımın daha iyi olduğu, insan sağlı̆̆ ise kimyasal gübrelemeye göre önemli ölçüde azaldığı saptanmıştır.
\end{abstract}

\section{ARTICLE INFO}

Received 28 September 2020

Received in revised form 20 January 2021

Accepted 01 February 2021

\section{Keywords:}

Vermicompost

Microbial fertilization

Head lettuce

Yield

Nitrate accumulation

\begin{abstract}
In this study, it was aimed to investigate the effects of vermicompost and microbial fertilizer application on the growth, yield and quality characteristics of head lettuce (Lactuca sativa $\mathrm{L}$. var. capitata cv Bombola). In the research carried out under PE greenhouse conditions, the plot size was $20 \mathrm{~m}^{2}$ and a chemical fertilization $(\mathrm{KG}), 3$ different doses of vermicompost $(0,100$, 200 ve $400 \mathrm{~kg} \mathrm{da}^{-1}$ ) and 2 application rates of microbial fertilizer (M- and $\mathrm{M}+$ ) were used according to randomized block trial design. Microbial fertilizer application was placed two times: before sowing as seed coating and after transplanting as soil drenching. The harvested lettuce plants were determined average head weight $\left(\mathrm{g}\right.$ plant $\left.{ }^{-1}\right)$, total yield $\left(\mathrm{kg} \mathrm{m}^{-2}\right)$, head length $(\mathrm{cm})$, head diameter $(\mathrm{cm})$, head fresh weight $(\mathrm{g})$, head dry weight $(\mathrm{g})$, leaf colour $(\mathrm{L}, \mathrm{a}, \mathrm{b}$, croma, hue), $\mathrm{pH}$, brix (\%), ascorbic acid (Vitamin C) $\left(\mathrm{mg} 100 \mathrm{~g}^{-1}\right)$ and nitrate $\left(\mathrm{mg} \mathrm{kg}^{-1}\right)$. According to the results of study, the application of $400 \mathrm{~kg} \mathrm{ha}^{-1}$ vermicompost and microbial fertilizer have been increased plant growth as same as chemical fertilization. In additional, the colour and other quality criteria of the microbial fertilized head lettuce were better than chemical fertilized head lettuce and accumulation of nitrate was decreased significantly.
\end{abstract}

\section{Giriş}

Nüfus artışı ile beraber, gıda ihtiyacının artması tarımda aşırı gübre ve kimyasal ilaç kullanımını ortaya çıkartmıştır. Tarımın sürdürülebilirliğini etkileyen bu durum özellikle topraklarda fiziksel, kimyasal ve biyolojik sorunlara sebep olarak çevre ve insan sağlığını olumsuz yönde etkilemektedir. Yoğun kimyasal ve gübre kullanımı önemli bir problem olarak görülmekte ve gerekli tedbirler alınması ötavsiye edilmektedir
(EEA 2009). Organik madde toprakta agregatlaşmayı teşvik eder, su ve katyon tutma kapasitesini artırır, mineralizasyon sonucu bitkilere besin maddesi sağlar ve mikroorganizma faaliyetlerini destekler (Aydın ve Kılıç 2010). Organik maddenin azlığı, doğal toprak yapısının bozulması, verim ve kalitenin düşmesi anlamına gelmektedir. Toprak organik madde 
miktarını artırma ve toprak yapısını iyileştirmek verimliliğin sürdürülebilirliği açısından önemlidir.

Vermikompost birçok farklı organik materyalin bazı toprak solucanları (Eisenia Foetida, Lumbricus Rubellus) tarafindan sindirilmesi sonucu elde edilen son yıllarda kullanımı yaygınlaşan, bitki tarafından doğrudan alınabilir bitki besin elementleri taşıyan, humik ve fulvik asitçe zengin, ahır gübresi gibi diğer organik materyallere göre daha ince ve geniş yüzey alanı içeren bir organik gübredir (Mısırlığlu 2011; Özkan ve ark. 2016). Vermikompost uygulamaları ile birçok bitkinin gelişiminin, veriminin ve bitki besin maddesi alınımının artığı bildirilmiştir (Arancon ve ark. 2004; Jahan ve ark. 2014; Eryüksel 2016; Özkan ve ark. 2016; Ak Göksu ve Öztokat Kuzucu 2017).

Mikoriza ve bitki gelişimini teşvik eden rizosfer bakterilerini içeren mikrobiyal gübreler, bitkiye bitki besin elementi alınımını sağlayarak veya bitki besin elementlerinin alınabilirliğini artırarak, bazı bitkisel hormonlar üreterek veya patojen gelişimini engelleyerek bitki gelişimi ve verimini artırırlar (Li 2001; Javorekova ve ark. 2015). Çevre dostu olan mikrobiyal gübreler kimyasal gübrelere önemli bir alternatiftirler (Parlak ve Güner 2017). Bacillus subtilis, Bacillus megaterium, Pantoea agglomerans ve Pseudomonas fluorenscens gibi bitki gelişimini teşvik eden bakteriler tarımda geniş kullanım potansiyeline sahip olup, mikrobiyel gübreler olarak kullanımları artmaktadır (Ryu ve ark. 2004; Castanheira ve ark. 2013). Bacillus ve Pseudomonas cinsi bakteriler üzerinde yapılan çalışmalarda; azot alınımını artırmaları (Çakmakçı ve ark. 2006), organik asitler yardımı ile inorganik fosfatın çözünürlüğü artırmaları (Rodriguez ve Fraga 1999; Nautiyal ve ark. 2000), antibiyotik sentezi (Rosado ve Seldin 1993; Vassilev ve ark. 1996) ve IAA gibi fitohormonların üretimini artırmaları (Vassilev ve ark. 1996) konuları öne çıkmıştır.

Baş bağlamayan kıvırcık yapraklı salata (Lactuca sativa L. var. Crispa) ve lahana gibi baş bağlayan baş salata (Lactuca sativa $\mathrm{L}$. var. capitata) dünyada geniş alanlarda yetiştirilen soğuğa kısmen dayanıklı tek yıllık bir serin iklim sebzeleridir. Yaprağı yenen sebzeler grubunda yer alan baş salatanın açıkta ve örtü altında değişik mevsimlere uygun islah edilmiş çeşitleri ile yılın 12 ayı üretim yapmak mümkündür. Bitki organik maddeyi sever ve organik maddece zengin topraklarda hızla gelişerek 2-3 ayda hasat olgunluğuna ulaşır. Organik madde bakımından fakir olan ülkemiz topraklarında baş salata üretiminde verim ve kaliteyi artırmak amacıyla aşırı inorganik gübreleme yapılmaktadır (Kavak ve ark. 2003). Özellikle yaprağ1 yenene sebzelerde nitrat birikimleri, nitrit'e dönüşüm ve daha sonra kansorejen nitrozamine dönüşüm insan sağlı̆̆ açısından önemli riskler oluşturmakta buna bağlı olarak günlük olarak alınan nitrat miktarının $5 \mathrm{mg} \mathrm{kg}^{-1}$ geçmemesi istenmektedir (Szwonek 1986). Organik gübre kaynaklarının yaprağı yenen sebzelerin yetiştiriciliğinde kullanımı inorganik gübrelemeye göre daha düşük nitrat birikimine neden olmaktadır (Raupp 1996).

$\mathrm{Bu}$ çalışma çiğ olarak tüketilerek insan beslenmesinde önemli yer tutan ve aşırı gübrelenmesi sonucu yapraklarında nitrat/nitrin birikimi riski taşıyan baş salata üretiminde, farklı dozlarda vermikompost ve mikrobiyal gübre uygulamasının bitki gelişimi, verim ve nitrat birikimi üzerine etkileri izlenmiştir.

\section{Materyal ve Yöntem}

Araştırma Muğla Sitkı Koçman Üniversitesi Ortaca Meslek Yüksekokuluna ait PE serada 2018 yılı ilkbahar döneminde bir adet kimyasal gübreleme $(\mathrm{KG})$ ile 4 farklı vermikompost ( 0 , 100,200 ve $400 \mathrm{~kg} \mathrm{da}^{-1}$ ) ve 2 farklı dozda ticari mikrobiyal gübre (M- ve $\mathrm{M}+)$ dozu olacak şekilde Bombola F1 baş salata (Lactuca sativa $\mathrm{L}$. var. capitata) çeşidinde 3 tekerrürlü olmak üzere tesadüf blokları deneme desenine göre yürütülmüştür. Kimyasal gübre uygulamas $15 \mathrm{~kg} \mathrm{da}^{-1} \mathrm{~N}, 10 \mathrm{~kg} \mathrm{da}^{-1} \mathrm{P}_{2} \mathrm{O}_{5}$ ve 18 $\mathrm{kg} \mathrm{da}{ }^{-1} \mathrm{~K}_{2} \mathrm{O}$ olacak şekilde taban gübrelemesi ile yapılmıştır (Vural ve ark. 2000) Çalışmamızda kullanılan organik materyal olarak kullanılan Eisenia fetida türü toprak solucanlarından elde edilen vermikompost yerel bir üreticiden temin edilmiş olup içeriği laboratuvar analizi ile teyit edilmiştir. Vermikompostun ve toprağın bazı fiziksel ve kimyasal özellikleri; bünye (Bouyoucos 1951), toprak reaksiyonu-pH ve toprak elektriksel iletkenliği-EC (1/2.5= toprak/su) Jackson (1967), kireç Çağlar (1949), organik madde Black (1965), toplam azot modifiye Kjeldahl (Kacar 1995), Vermikompostta toplam P, K, Ca, Mg, $\mathrm{Fe}, \mathrm{Mn}, \mathrm{Zn}$ ve $\mathrm{Cu}$ analizleri yaş yakma ile (Kacar ve İnan 2010) ICP cihazında okunarak, toprakta alınabilir P olsen yöntemine göre (Olsen ve Dean 1965), değişebilir K, Mg ve Ca Kacar (1995)'e göre, alınabilir Fe, Zn, Mn ve Cu Lindsay ve Norvell (1978)'e göre belirlenmiş ve Çizelge 1'de verilmiştir.

Çizelge 1. Çalışmada kullanılan vermikompostun ve toprağın fiziksel ve kimyasal özellikleri.

Table 1. Some physical and chemical properties of soil and vermicompost used in the study.

\begin{tabular}{lll}
\hline \multicolumn{1}{c}{ Parametreler } & Toprak & Vermikompost \\
\hline Bünye & Killi Tın & - \\
pH $(1: 2.5)$ su & 7.46 & 7.82 \\
EC $(1: 2.5) \mathrm{dS} \mathrm{m}^{-1}$ & 0.277 & 4.89 \\
Kireç (\%) & 20.1 & - \\
Organik Madde (\%) & 1.27 & 47.5 \\
Toplam N (\%) & 0.11 & 1.84 \\
$\mathrm{C} / \mathrm{N}$ & 6.18 & 15.24 \\
$\mathrm{P}(\mathrm{ppm})$ & 4.81 (alınabilir) & 3541 (toplam) \\
$\mathrm{K}(\mathrm{ppm})$ & 110.4 (değişebilir) & 6877 (toplam) \\
$\mathrm{Ca}(\mathrm{ppm})$ & 7524 (değişebilir) & 6214 (toplam) \\
$\mathrm{Mg}(\mathrm{ppm})$ & 941.3 (değişebilir) & 1124 (toplam) \\
$\mathrm{Mn}(\mathrm{ppm})$ & 4.45 (alınabilir) & 23.25 (toplam) \\
$\mathrm{Zn}(\mathrm{ppm})$ & 0.112 (alınabilir) & 37.55 (toplam) \\
$\mathrm{Cu}(\mathrm{ppm})$ & 3.184 (alınabilir) & 9.01 (toplam) \\
$\mathrm{Fe}(\mathrm{ppm})$ & 8.78 (alınabilir) & 72.75 (toplam) \\
\hline
\end{tabular}

Ticari mikrobiyal gübre (Bmusa Green, Bmusa Microbial, Antalya) Bacillus megaterium RC07 $\left(1 \times 10^{7} \mathrm{kob} \mathrm{ml}^{-1}\right)$, Bacillus subtilis RC521 $\left(1 \times 10^{7} \mathrm{kob} \mathrm{ml}^{-1}\right)$ ve Pseudomonas fluorescens RC512 (1 x $\left.10^{7} \mathrm{kob} \mathrm{m}^{-1}\right)$ içermektedir. Baş salata tohumları \%2'lik Sodyum hipoklorit çözeltisinde 3 dakika yüzey strilizasyona tabi tutulmuş, streril saf suda $3 \mathrm{kez}$ y1kandıktan sonra, uygulama tohumları \% 1.5 'lik karboksimetil selüloz kullanılarak bakteri yoğunluğu $10^{5}-10^{6} \mathrm{kob} \mathrm{ml}^{-1}$ olacak şekilde kaplanmıştır. Kontrol olarak ayrılan tohumlara strerilizasyondan sonra sadece \%1.5'lik karboksimetil selüloz uygulanmıştır. Kaplama işleminde tohumlar bakteri içeren çözeltide 30 dakika boyunca 150 devir dakika ${ }^{-1}$ olacak şekilde çalkalanmış ve ekimden önce gölge bir yerde 12 saat 
kurutulmuştur. Tohumlar 10 Ocak 2018 tarihinde, steril torf içeren $210^{\prime}$ luk multipotlara ekilerek, 3 gün $18 / 18^{\circ} \mathrm{C}$ gece $/$ gündüz sıcaklık ve $\% 80$ nisbi nemde çimlenme dolabında karanlıkta tutulduktan sonra seraya taşınmıştır. Ayrıca dikim öncesi fidelerin gerekli bakım ve sulama işlemleri düzenli olarak yapılmıştır.

Dikim öncesi 4 farklı dozda vermikompost deneme parsellerine karıştırılmıştır. Her bir uygulama için deneme parselleri $20 \mathrm{~m}^{2}$ olarak planlanmış her bir uygulama arasına $1 \mathrm{~m}$ olacak şekilde emniyet alanı bırakılmışır. 3-4 gerçek yapraklı hale gelen fideler 18 Şubat 2018 tarihinde metre karede 8.88 adet bitki olacak şekilde $(0.9$ x $0.5 \times 0.25 \mathrm{~m})$ dikilmiştir. Dikimden bir hafta sonra, mikrobiyal gübre 100 kat sulandırılarak $\left(10^{5} \mathrm{kob} \mathrm{ml}^{-1}\right)$ kök boğazına bitki başına $30 \mathrm{ml}$ olarak uygulanmıştır. Mikrobiyal gübre uygulaması yapılmayan parseller aynı miktarda saf su ilavesi yapılmıştır. Yetiştiricilik süresince sulama ve bakım işlemleri tüm parseller eşit olacak şekilde yürütülmüş. Bitkiler damlama sulama sistemi ile sulanmıştır. Çalışma süresince gerçekleşen sera içi iklim verileri "Hobo Veri Kaydedici" cihazı ile kaydedilmiştir. Yetiştirme dönemi boyunca sera iç sıcaklığı minimum ve maksimum olmak üzere sırasıyla $11.5-36.9^{\circ} \mathrm{C}$, nisbi nem değeri minimum ve maksimum olmak üzere sirasıyla \%35.7- \%87.6 aralığın da ölçülmüsşür. Baş salata bitkileri çeşide göre irilik ve renginin aldığı zaman, dikimden 72 gün sonra 30 Nisan 2018 tarihinde hasat bir defada yapılmıştır.

Hasat edilen bitkilerde verim ve bitki gelişimini belirlemek için, ortalama baş ağırlığı $\left(\mathrm{g} \mathrm{bitki}^{-1}\right)$, toplam verim $\left(\mathrm{kg} \mathrm{m}^{-2}\right)$, her parselden rastgele seçilen 5 adet bitkide baş boyu $(\mathrm{cm})$ ve baş çap1 $(\mathrm{cm})$, yaprak rengi, baş yaş ağırlığı $(\mathrm{g})$ ve baş kuru ağırlığı (g) ölçülmüştür. Baş boyu; kök boğazında itibaren başın en yüksek noktasına kadar olan mesafenin metre ile ölçülmesi, baş çapı; başın orta noktasının eninin metre ile ölçülmesi ile elde edilmiştir. Yaprak rengi ölçümü için Minolta CR300 marka renk ölçer kullanılmış, $L$, a, b değerleri okunmuş, a ve b değerleri üzerinden de hue ve croma değerleri belirlenmiştir (McGuire 1992). Baş yaş ağırlığı (YA) için tartılan bitkiler kese kağıdı içerisinde $65^{\circ} \mathrm{C}$ hava sirkülasyonlu kurutma dolabında sabit ağırlığa gelinceye kadar kurutulmuş, baş kuru ağırlığ (KA) tartılarak ölçülmüştür. Baş yaş ve kuru ağırlığ değerleri kullanılarak \% baş kuru madde (KM) değeri elde edilmiştir. Her parselden rasgele seçilen 2 adet bitkinin 100 gram yaprağından çıkarılan usarelerde $\mathrm{pH}$ ve suda çözünebilir kuru madde (\% SÇKM) değeri ölçülmüş, Askorbik asit (Vitamin C) miktarları $\left(\mathrm{mg} 100 \mathrm{~g}^{-1}\right)$ oksalik asit ile stabilize edilmiş örneklerin 2-6 diklorofenlindefenol boya maddesi ile renklendirilmesi esasına göre spektrofotometrik (UT-80) yöntemle belirlenmiştir (Pearson ve Churchill 1970). Nitrat içeriğinin belirlenmesinde salisilik asit ve sodyum hidroksit ile ekstrasyon ve spektrofotometrik (UT-80) yöntem kullanılmıştır (Fresenius ve ark. 1998).

Çalışmadan elde edilen veriler IBM ${ }^{\circledR}$ SPSS ${ }^{\circledR}$ Statistics 12 (IBM, NY, USA) istatistik paket programı kullanılarak varyans analizine tabi tutulmuştur. Her uygulama için ortalamalar arasındaki farklılıklar Duncan testi $(\mathrm{P} \leq 0.05)$ ile belirlenmiştir.

\section{Bulgular ve Tartışma}

Mikrobiyal gübre ve vermikompost uygulamalarının ana ve interaksiyon etkileri ortalama baş ağırlığı, toplam verim, baş yaş, kuru ve kuru madde miktarı değerleri bakımından incelendiğinde ana etkilerin istatistiki açıdan önemli $(\mathrm{P} \leq 0.05)$ olduğu belirlenmiştir (Çizelge 2). İnteraksiyon etkisi baş yaş ağırlığı hariç önemli bulunmamıştır. Mikrobiyal gübre uygulanmış bitkiler uygulanmayan bitkilere göre ortalama baş ağırlığ bakımından $\% 12.98$, toplam verimde $\% 11.20$, baş yaş ağırlığında \%12.70, baş kuru ağırlığında \%15.58 ve baş kuru madde miktarında \%3.55 oranında daha yüksek değerler vermişlerdir. Vermikompost uygulamaları karşılaştırıldığında tüm bakılan parametrelerde en düşük değerler vermikompost ve kimyasal gübrelemenin yapılmadığı (V0) uygulamasında izlenirken, en yüksek değerler ise $400 \mathrm{~kg} \mathrm{da}^{-1}$ vermikompost (V400) uygulamasında elde edilmiştir. V400 uygulaması ortalama baş ağırlığının ve toplam verimi V0 uygulamasına göre sırasıyla $\% 40.24$ ve $\% 56.61$ oranında artırmıştır. V400 uygulaması ile kimyasal gübre $(\mathrm{KG})$ uygulaması istatistiki olarak tüm verim parametreleri bakımın aynı gruplandırmada yer almışlardır. Marulda ve kıvırcık salatada vermikompost gübrelemesinin verim, yaş ve kuru ağılık ve yüzde kuru ağırlık üzerine olumlu etkileri birçok çalışmada bildirilmiştir (Premuzic ve ark. 2002; Coria-Cayupan ve ark. 2009; Papathanasiou ve ark. 2012; Üçok ve ark. 2019).

Kimyasal gübre, vermikompost ve mikrobiyal gübre uygulamalarının baş boyu, baş çapı ve renk değerleri üzerine etkisi Çizelge 3'de verilmiștir. Mikrobiyal gübre uygulaması ve vermikompost uygulamalarının ana etkileri baş boyu ve baş çapı üzerine istatistiki olarak etkili bulunurken, interaksiyon etkisi önemsiz bulunmuştur. Mikrobiyal gübre uygulaması baş boyu ve baş çapını arttırmıştır. Vermikompost uygulamalarının etkisi değerlendirildiğinde, en yüksek baş boyu $\mathrm{KG}$ uygulamasında $23.90 \mathrm{~cm}$ olarak saptanmış, bu değeri V400 uygulaması bitkileri $23.73 \mathrm{~cm}$ baş boyu değeri ile izlemişlerdir. Her iki uygulamada aynı istatistiki gruplandırmada yer almıştır. Baş çapı değeri bakımından en yüksek değer $15.80 \mathrm{~cm}$ ile V400 uygulamasından elde edilmiş, bunu aynı istatistiki gruplandırmada yer alan KG uygulaması $15.62 \mathrm{~cm}$ ile izlemiştir. Yapılan birçok çalışmada mikoriza (Baslam ve ark. 2011; Kardüz ve ark. 2015; Karipçin ve Şatır 2016) veya kök bakterileri (Çakmakçı 2005; Karagöz ve Kotan 2010; Shehata ve ark. 2016) kullanımı ile bitki gelişiminin artığ saptanmıştır. Ana uygulamaların baş salata bitkisinin renk değerleri üzerine, $\mathrm{L}$ değeri hariç $\mathrm{P} \leq 0.01$ düzeyinde önemli etkisi olurken, interaksiyon önemsiz bulunmuştur. Yaprak yeşil rengini gösteren a değerleri değerlendirildiğinde mikrobiyal gübre uygulanmış bitkiler uygulanmayanlara göre daha düşük değer (-18.9) vermişler, bu bitkilerin dıș yaprakları daha koyu yeșil renge sahip olmuşlardır. Mikrobiyal gübre uygulaması uygulanmayan bitkilere göre daha yüksek croma (133.5) ve hue (28.51) değerleri oluşturarak, bu bitkilerin daha dolgun bir yeşil renge sahip olmasını sağlamıştır. Vermikompost ve $\mathrm{KG}$ uygulamalarına bakıldığında, V400 ve KG uygulamasının en yüksek a, b, hue ve croma değerlerini verdiği istatistiki olarak aynı gruplandırmada yer aldıkları saptanmıștır. Bu bitkiler daha yoğun ve koyu yeşil renge sahip diş yapraklar oluşturmuşlardır. Organik salata-marul yetiştiriciliği ile ilgili yapılan bir çalışmada, farklı organik gübrelerin verim ve kalite üzerine etkilerini incelenmiş $\mathrm{L}$ değeri 47.4 ila 53.6, a değeri -14.5 ila -19.2 , b değeri ise 21.3 ala 29.9 aralığında saptanmış, croma değerinin en yüksek olarak solucan gübresi ve kimyasal gübre uygulamasında olduğunu bildirmiştir (Üçok ve ark. 2019)

Mikrobiyal gübre ve vermikompost ana uygulamaları Vitamin $\mathrm{C}$ değerinin istatistiki olarak etkilemiş, mikrobiyal gübrenin ilavesi sonucu Vitamin $\mathrm{C}$ değeri ilave edilmeyen uygulamalara göre $\% 6.45$ oranında daha yüksek bir değer bulunmuştur (Çizelge 4). En düşük Vitamin $C$ değeri gübreleme yapılmayan V0 uygulamasında $0.605 \mathrm{mg} 100 \mathrm{~g}^{-1}$ olarak saptanırken, vermikompost uygulama dozları ile Vitamin C 
Çizelge 2. Mikrobiyal gübre ve vermikompost uygulamalarının baş salata yetiştiriciliğinde baş ağırlığı $\left(\mathrm{g}\right.$ bitki $\left.^{-1}\right)$, toplam verim $\left(\mathrm{kg} \mathrm{m}^{-2}\right)$, baş yaş $(\mathrm{g})$ ve kuru ağırlı̆̆ $(\mathrm{g})$, kuru madde miktarı (\%) üzerine etkileri.

Table 2. The effect of vermicompost and microbial fertilizer on mean heat weight ( $\left.\mathrm{g} \mathrm{plant}^{-1}\right)$, total yield $\left(\mathrm{kg} \mathrm{m}^{-2}\right)$, head fresh weight $(\mathrm{g})$, head dry weight ( $\mathrm{g})$, Dry mater (\%) of head lettuce.

\begin{tabular}{|c|c|c|c|c|c|c|}
\hline \multirow{2}{*}{\multicolumn{2}{|c|}{ Uygulamalar }} & \multirow{3}{*}{$\begin{array}{c}\begin{array}{c}\text { Ortalama Bass A Ağırlı̆̆ } \\
\left(\mathbf{g ~ b i t k i ~}^{-1}\right)\end{array} \\
498.1 \mathrm{~b}\end{array}$} & \multirow{3}{*}{$\begin{array}{c}\begin{array}{c}\text { Toplam verim } \\
\left(\mathbf{k g ~ ~ ^ { - 2 }}\right)\end{array} \\
3.57 \mathrm{~b}\end{array}$} & \multicolumn{3}{|c|}{ Baş } \\
\hline & & & & \multirow{2}{*}{$\frac{\text { YA (g) }}{501.3 \mathrm{~b}}$} & \multirow{2}{*}{$\frac{\mathbf{K} \mathbf{A}(\mathbf{g})}{15.53 \mathrm{~b}}$} & \multirow{2}{*}{$\frac{\mathbf{K ~ M}(\%)}{3.09 \mathrm{~b}}$} \\
\hline Mikrobiyal Gübre & M- & & & & & \\
\hline & $\mathrm{M}+$ & $562.8 \mathrm{a}$ & $3.97 \mathrm{a}$ & $565.0 \mathrm{a}$ & $17.95 \mathrm{a}$ & $3.20 \mathrm{a}$ \\
\hline \multirow[t]{5}{*}{ Vermikompost } & KG & $589.4 \mathrm{a}$ & $4.63 \mathrm{a}$ & $592.9 \mathrm{~b}$ & $19.1 \mathrm{a}$ & $3.28 \mathrm{a}$ \\
\hline & V0 & $427.6 \mathrm{c}$ & $2.95 \mathrm{~d}$ & $451.1 \mathrm{~d}$ & $13.2 \mathrm{~d}$ & $2.89 \mathrm{c}$ \\
\hline & V100 & $481.1 \mathrm{c}$ & $3.27 \mathrm{c}$ & $484.6 \mathrm{c}$ & $15.5 \mathrm{c}$ & $3.13 \mathrm{~b}$ \\
\hline & V200 & $574.5 \mathrm{~b}$ & $3.69 \mathrm{~b}$ & $562.0 \mathrm{~b}$ & $17.9 \mathrm{~b}$ & $3.17 \mathrm{~b}$ \\
\hline & V400 & $599.7 \mathrm{a}$ & $4.62 \mathrm{a}$ & $605.6 \mathrm{a}$ & $20.5 \mathrm{a}$ & $3.36 \mathrm{a}$ \\
\hline Mikrobiyal Gübre & & $* *$ & ** & $* *$ & $* *$ & $* *$ \\
\hline Vermikompost & & $* *$ & $* *$ & $* *$ & $* *$ & $* *$ \\
\hline Mikrobiyal Gübre x & mpost & Ö.d & Ö.d & $*$ & Ö.d & Ö.d \\
\hline
\end{tabular}

Ö.d: önemli değil, *:P $\leq 0.05$, **: P $\leq 0.01$, YA: Yaş ağırlık, KA: Kuru Ağırlık, KM: Kuru Madde, KG: Kimyasal Gübreleme, M-:Mikrobiyal Gübre yok, M+: Mikrobiyal Gübre var.

Ö.d: Not significant, *:P $\leq 0.05$, **: P $\leq 0.01$, YA: Head Fresh Weight, KA: Head Dry Weight, KM: Head Dry Mater, KG: Chemical Fertilization, M-: No Microbial Fertilizer, M+: Microbial Fertilizer.

Çizelge 3. Mikrobiyal gübre ve vermikompost uygulamalarının baş salata yetiştiriciliğinde baş boyu $(\mathrm{cm})$, baş çapı $(\mathrm{cm})$ ve renk özellikleri üzerine etkileri.

Table 3. The effect of vermicompost and microbial fertilizer on heat width $(\mathrm{cm})$, head length $(\mathrm{cm})$ and colour properties of head lettuce.

\begin{tabular}{|c|c|c|c|c|c|c|c|c|}
\hline \multirow{2}{*}{\multicolumn{2}{|c|}{ Uygulamalar }} & \multirow{3}{*}{$\begin{array}{c}\text { Baş Boyu } \\
\text { (cm) }\end{array}$} & \multirow{3}{*}{$\begin{array}{c}\text { Baş Çapı } \\
(\mathbf{c m})\end{array}$} & \multicolumn{3}{|c|}{ Renk } & \multirow{3}{*}{$\begin{array}{c}\text { Hue } \\
130.7 \mathrm{~b}\end{array}$} & \multirow{3}{*}{$\begin{array}{l}\text { Croma } \\
24.81 \mathrm{~b}\end{array}$} \\
\hline & & & & \multirow{2}{*}{$\begin{array}{c}\mathbf{L} \\
51.3\end{array}$} & \multirow{2}{*}{$\frac{\mathbf{a}}{-17.2 \mathrm{~b}}$} & \multirow{2}{*}{$\frac{\text { b }}{17.65 \mathrm{~b}}$} & & \\
\hline Mikrobiyal Gübre & M- & & & & & & & \\
\hline & $\mathrm{M}+$ & $22.61 \mathrm{a}$ & $15.23 \mathrm{a}$ & 52.0 & $-18.9 \mathrm{a}$ & $19.01 \mathrm{a}$ & $133.5 \mathrm{a}$ & $28.51 \mathrm{a}$ \\
\hline Vermikompost & $\mathrm{KG}$ & $23.90 \mathrm{a}$ & $15.62 \mathrm{a}$ & 52.9 & $-19.8 \mathrm{a}$ & $19.50 \mathrm{a}$ & $135.6 \mathrm{a}$ & $26.82 \mathrm{a}$ \\
\hline & V0 & $20.70 \mathrm{c}$ & $13.70 \mathrm{c}$ & 50.1 & $-16.4 c$ & $17.11 \mathrm{c}$ & $125.6 \mathrm{~d}$ & $23.13 d$ \\
\hline & V100 & $20.62 \mathrm{c}$ & $14.79 \mathrm{~b}$ & 50.5 & $-16.9 c$ & $17.55 \mathrm{c}$ & $127.2 \mathrm{c}$ & $24.74 \mathrm{c}$ \\
\hline & V200 & $22.48 \mathrm{~b}$ & $15.05 \mathrm{~b}$ & 51.7 & $-17.8 b$ & $18.55 b$ & $130.4 \mathrm{~b}$ & $25.87 \mathrm{~b}$ \\
\hline & V400 & $23.73 \mathrm{a}$ & $15.80 \mathrm{a}$ & 52.7 & $-20.1 \mathrm{a}$ & $19.47 \mathrm{a}$ & $135.3 \mathrm{a}$ & $26.86 \mathrm{a}$ \\
\hline Mikrobiyal Gübre & & $* *$ & $* *$ & Ö.d & ** & $* *$ & $* *$ & $* *$ \\
\hline Vermikompost & & $* *$ & $* *$ & Ö.d & $* *$ & $* *$ & $*$ & $* *$ \\
\hline Mikrobiyal Gübre & ermikompost & Ö.d & Ö.d & Ö.d & Ö.d & Ö.d & Ö.d & Ö.d \\
\hline
\end{tabular}

Ö.d: önemli değil, *:P $\leq 0.05, * *: \mathrm{P} \leq 0.01, \mathrm{KG}$ : Kimyasal Gübreleme, M-:Mikrobiyal Gübre yok, M+: Mikrobiyal Gübre var.

Ö.d: Not significant, *:P $\leq 0.05$, **: $\mathrm{P} \leq 0.01$, KG: Chemical Fertilization, M-: No Microbial Fertilizer, M+: Microbial Fertilizer.

Çizelge 4. Mikrobiyal gübre ve vermikompost uygulamalarının baş salata yetiştiriciliğinde Vitamin C ve SÇKM üzerine etkileri.

Table 4. The effect of vermicompost and microbial fertilizer on Vitamin $\mathrm{C}, \mathrm{pH}$ and brix on head lettuce.

\begin{tabular}{|c|c|c|c|c|c|}
\hline \multicolumn{2}{|c|}{ Uygulamalar } & \multirow{2}{*}{$\frac{\text { Vitamin } \mathbf{C}\left(\mathbf{m g ~} \mathbf{1 0 0} \mathbf{g}^{-1}\right)}{0.605 \mathrm{~b}}$} & \multirow{2}{*}{$\begin{array}{l}\mathbf{p H} \\
5.91\end{array}$} & \multirow{2}{*}{$\begin{array}{c}\text { SÇKM (\%) } \\
4.26\end{array}$} & \multirow{2}{*}{$\frac{\text { Nitrat }\left(\mathbf{m g ~ k g}^{-1}\right)}{755.6 \mathrm{~b}}$} \\
\hline Mikrobiyal Gübre & M- & & & & \\
\hline & $\mathrm{M}+$ & $0.644 \mathrm{a}$ & 5.91 & 4.32 & $955.2 \mathrm{a}$ \\
\hline \multirow[t]{5}{*}{ Vermikompost } & KG & $0.604 \mathrm{c}$ & 5.92 & 4.41 & $1738.2 \mathrm{a}$ \\
\hline & V0 & $0.594 \mathrm{~d}$ & 5.91 & 4.12 & $640.1 \mathrm{~d}$ \\
\hline & V100 & $0.612 \mathrm{c}$ & 5.92 & 4.17 & $789.5 \mathrm{c}$ \\
\hline & V200 & $0.644 \mathrm{~b}$ & 5.89 & 4.34 & $985.8 \mathrm{~b}$ \\
\hline & V400 & $0.670 \mathrm{a}$ & 5.91 & 4.40 & $1075.7 \mathrm{~b}$ \\
\hline \multicolumn{2}{|c|}{ Mikrobiyal Gübre (MG) } & $* *$ & Ö.d & Ö.d & *** \\
\hline \multicolumn{2}{|c|}{ Vermikompost (V) } & $* *$ & Ö.d & Ö.d & $* *$ \\
\hline \multicolumn{2}{|c|}{ Mikrobiyal Gübre x Vermikompost } & Ö.d & Ö.d & Ö.d & Ö.d \\
\hline
\end{tabular}

Ö.d: önemli değil, *:P $\leq 0.05, * *: \mathrm{P} \leq 0.01, \mathrm{KG}$ : Kimyasal Gübreleme, M-:Mikrobiyal Gübre yok, M+: Mikrobiyal Gübre var.

Ö.d: Not significant, *:P $\leq 0.05$, **: $\mathrm{P} \leq 0.01$, KG: Chemical Fertilization, M-: No Microbial Fertilizer, M+: Microbial Fertilizer.

miktarı artmıștır. Kimyasal gübrelemeye göre organik gübreleme daha yüksek Vitamin $\mathrm{C}$ değerleri oluşturmuştur. Çalışmada uygulamaların $\mathrm{pH}$ ve SÇKM üzerine etkisi istatistiksel olarak önemsiz bulunmuştur. Yeşil sebzelerde yapılan birçok çalışmada, Vitamin $\mathrm{C}$ biyosentezindeki azalmadan topraktaki yüksek mineral azot seviyesinin sorumlu olduğu bildirilmiștir (Mozafar 1996; Chiesa ve ark. 2009; Papathanasiou ve ark. 2012). Premuzic ve ark. (2002), iki organik gübre (vermikompost ve kompost) ve iki kimyasal gübrelemenin marul yetiştiriciliğinde verim ve kalite üzerine etkilerini inceledikleri çalışmalarında, kimyasal gübrelemelerde Vitamin C miktarının organik gübrelemelere göre daha düşük 
olduğunu bildirmişlerdir. Yapraklardaki nitrat içeriği incelendiğinde, mikrobiyal gübre uygulamasında uygulanmayanlara göre nitrat birikimi daha yüksek bulunmuştur. Vermikompost ve kimyasal gübre uygulamalarında ise en yüksek nitrat birikimi KG uygulamasında $1738.2 \quad \mathrm{mg} \mathrm{kg}^{-1}$ olarak saptanmıştır. Vermikompost uygulama dozlarında ise doz artışına bağlı olarak nitrat birikimi artmış olsa da en yüksek doz olan V400 uygulamasında nitrat birikimi KG uygulamasına göre \%38.11 oranında daha düşüktür. Beslenme yolu ile alınan nitrat bağırsaklarda bakteriyel nitrat redüktaz aktivitesi ile nitrite dönüşerek, kandaki hemoglobini etkilemekte kandaki $\mathrm{O}_{2}$ taşınımını azalmaktadır (Cemek ve ark. 2007). İlaveten sekonder aminlerle tepkimeye giren nitrit potansiyel kanserojen nitroaminlerin oluşumuna sebep olmaktadır (Connolly ve Paul 2001). Türk gıda kodeksine göre baş salata için belirlenen maksimum nitrat sınırı 2000-2500 mg kg-1 olarak belirlenmiştir (Resmi Gazete 2008). Uygulamalarımızın tümünde nitrat birikimi bu sınır değerin altında olup en yakın değer $\mathrm{KG}$ uygulamasındadır. Vermikompost uygulamasının en yüksek dozu bile kimyasal gübre uygulamasına göre daha düşük nitrat birikimi oluşturmuştur. Bitki besin maddesi alınımını artıran mikrobiyal gübreler nitrat birikimini artırsa da bu değerler insan sağlı̆̆1 bakımından riskli değerlerin çok altındadır. Farklı kimyasal gübre uygulamalarının, farklı organik gübrelemeler ile karşılaştırıldığı birçok çalışmada, organik gübreleme ile kimyasal gübrelemeye göre marul ve salata grubunda nitrat birikiminin azaldığı bildirilmiştir (Ricci ve ark. 1995; Premuzic ve ark. 2002; Papathanasiou ve ark. 2012).

\section{Sonuç}

Vermikompost kullanımı organik madde ihtiyacını karşılamak yanında, solucanın salgılarının da sağladı ğı ilave faydalar ile toprakların sürdürülebilirliğinin devamını sağlayacak bir uygulamadır. Vermikompostun inorganik gübrelere göre yavaş salınımlı olması, özellikle yeşil yaprakları tüketilen sebzelerde zararlı nitrat birikiminin önüne geçmektedir. Mikrobiyal gübreler bitki kök bölgesinde koloniler oluşturan, özellikle azot ve fosfor alınımı sağlayarak bitki gelişimine katkıda bulunan, canlı mikroorganizma içerir. Buna bağl1 olarak mikrobiyal gübrelerin kullanımı kimyasal gübre kullanımını azaltan çevre dostu bir tarım uygulamasıdır. Çalışmamızda baş salata yetiştiriciliğinde kimyasal gübrelemeye alternatif vermikompost ve bakteriyel kökenli mikrobiyal gübrelemenin beraber kullanımı incelenmiş, 400 $\mathrm{kg} \mathrm{da}^{-1}$ vermikompost ve mikrobiyal gübre uygulamasının kimyasal gübreleme ile aynı şekilde bitki gelişimini oluşturabildiği ve elde edilen bitkilerin renk ve diğer kalite kriterleri bakımın daha iyi olduğu, sağlık açısından risk oluşturan nitrat birikiminin ise kimyasal gübrelemeye göre önemli ölçüde azaldığı saptanmıştır. Bu çalışmadan elde edilen sonuçların güvenirliğini arttırmak amacıyla vermikompost ve mikrobiyal gübrenin uzun süreli kullanımı ile bitki çeşidi, iklim koşulları ve toprak tipinin farklı olduğu detaylı çalışmaların yapılması faydalı olacaktır.

\section{Kaynaklar}

Ak Göksu G, Öztokat Kuzucu C (2017) Karpuzda (Citrullus lanatus Thunb cv. Crimson Sweet) farkl dozlardaki vermikompost uygulamalarının verim ve bazı kalite parametrelerine etkisi. Çanakkale Onsekiz Mart Üniversitesi, Fen Bilimleri Enstitüsü Dergisi 3(2): 48-58.
Arancon NQ, Edwards CA, Atiyeh R, Metzger JD (2004) Effects of vermicomposts produced from food waste on the growth and yields of greenhouse peppers. Bio Resource Technology 93: 139-144.

Aydın M, Kılıç Ş (2010) Toprak Bilimi, Nobel Yayın Dağıtım Tic. Ltd. Şti., Nobel Yayın No: 1568, Ankara.

Baslam M, Garmendia I, Goicoechea N (2011) Arbuscular mycorrhizal fungi (AMF) improved growth and nutritional quality of greenhouse-grown lettuce. Journal of Agricultural and Food Chemistry 59(10): 5504-5515.

Black CA (1965) Methods of Soil Analysis. Part 2, American Society of Agronomy Inc., Publisher Madisson, Wilconsin, USA.

Bouyoucos GJ (1951) A recalibration of hydrometer method for making mechanical analysis of soils. Agronomy Journal 43: 434-438.

Castanheira N, Dourado AC, Alves PI, Cortes-Pallero AM, DelgadoRodriguez AI, Prazeres A, Borges N, Sanchez C, Crespo MTB, Fareleira P (2013) Annual ryegrass-associated bacteria with potential for plant growth promotion. Microbiological Research 169: 768-779.

Cemek M, Akkaya L, Birdane YO, Seyrek K, Bulut S, Konuk M (2007) Nitrate and nitrite levels in fruity and natural mineral waters marketed in western Turkey. Journal of Food Composition and Analysis 20: 236-240.

Chiesa A, León A, Mayorga I (2009) Quality of fresh cut lettuce (Lactuca sativa L.) as affected by lettuce genotype, nitrogen fertilization and crop season. Advances in Horticultural Science [rivista dell'ortofloroftutticoltura italiana] 23(3): 1000-1007.

Connolly D, Paul B (2001) Rapid determination of nitrate and nitrite in drinking water samples using ion-interaction liquid chromatography. Analytica Chimica Acta 441: 53-62.

Coria-Cayupán YS, Sánchez de Pinto MI, Nazareno MA (2009) Variations in bioactive substance contents and crop yields of lettuce (Lactuca sativa L.) cultivated in soils with different fertilization treatments. Journal of Agricultural and Food Chemistry 57(21): 10122-10129.

Çağlar KÖ (1949) Toprak Bilgisi. Ankara Üniversitesi Ziraat Fakültesi Yayınları, Sayı: 10.

Çakmakçı R (2005) Bitki gelişimini teşvik eden rizobakterilerin tarımda kullanımı. Atatürk Üniversitesi Ziraat Fakültesi Dergisi 36: 97-107.

Çakmakçı R, Donmez F, Aydın A, Sahin F (2006) Growth promotion of plants by plant growth-promoting rhizobacteria under greenhouse and two different field soil conditions. Soil Biology and Biochemistry 38(6): 1482-1487.

EEA (2009) Water resources across Europe: Confronting water scarcity and drought. Environ. Agency. Copenhagen. http://www.eea.europa.eu/publications/water-resourcesacrosseurope. Accessed 10 March 2019.

Eryüksel S (2016) Farklı oranlarda vermikompost uygulamasının bazı sebzelerin besin elementi içeriklerine olan etkileri. Yüksek Lisans Tezi, Namık Kemal Üniversitesi, Fen Bilimleri Enstitüsü, Tekirdağ.

Fresenius W, Quentin KE, Schneider W (1998) Water Analyis. A practical Quide to Physicochemical, Chemical and Microbiological Water Examination and Quality Assurance. Springer-Verlag, Berlin.

Jackson ML (1967) Soil Chemical Analysis. Prentice Hall of India Private Limited, New Delhi.

Jahan FN, Shahjalal ATM, Paul AK, Mehraj H, Jamaluddin AFM (2014) Efficacy of vermicompost and conventional compost on growth and yield of cauliflower. Bangladesh Research Publications Journal 10(1): 33-38.

Javorekova S, Makova J, Medo J, Kovacsova S, Charousova I, Horak J (2015) Effect of bio-fertilizers application on microbial diversity and physiological profiling of microorganisms in arable soil. Eurasian Journal of Soil Science 4: 54-61. 
Kacar B (1995) Bitki ve Toprağın Kimyasal Analizleri, III Toprak Analizleri. Ankara Üniversitesi Ziraat Fakültesi Eğitim, Araştırma ve Geliştirme Vakfı Yayınları, No: 3, Ankara.

Kacar B, İnal A (2010) Bitki analizleri. Nobel Yayınları No: 1241, Ankara.

Karagöz K, Kotan R (2016) Bitki gelişimini teşvik eden bazı bakterilerin marulun gelişimi ve Bakteriyel yaprak lekesi hastalığ üzerine etkileri. Türkiye Biyolojik Mücadele Dergisi 1(2): 165-179.

Kardüz Y, Tüzel Y, Öztekin GB (2015) Kapilar Sistemde Salata-Marul Yetiştiriciliğinde Mikoriza Uygulaması. Ege Üniversitesi Ziraat Fakültesi Dergisi 52(2): 151-159.

Karipçin MZ, Şatır NY (2016) Su stresi koșullarında yetiştirilen marul sebzesinin verim ve besin içeriğine Arbusküler Mikorizal Fungus (AMF)'un etkileri. Yüzüncü Y1l Üniversitesi Tarım Bilimleri Dergisi 26(3): 406-413.

Kavak S, Bozokalfa M, Uğur A, Yağmur B, Eşiyok D (2003) Farklı azot kaynaklarının baş salatada (Lactuca sativa var. capitata) verim, kalite ve mineral madde miktarı üzerine etkisi. Ege Üniversitesi Ziraat Fakültesi Dergisi 40(3): 33-40.

Li J (2001) Microbial rertilizer research. Biology Bulletin 36(7): 5-7.

Lindsay WL, Norvell WA (1978) Development of a DTPA soil test for zinc, iron, manganese and copper. Soil Science Society of America Journal 42(3): 421-428.

McGuire GR (1992) Reporting of objective color measurements. HortScience 27(12): 1254-1255.

Misırlığlu M (2011) Toprak Solucanları, Biyolojileri, Ekolojileri ve Türkiye Türleri. Nobel Yayınları No: 1636, Ankara.

Mozafar A (1996) Decreasing the NO3 and increasing the vitamin C contents in spinach by a nitrogen deprivation method. Plant Foods for Human Nutrition 49: 155-162.

Nautiyal CS, Bhadauria S, Kumar P, Lal H, Mondal R, Verma D (2000) Stress induced phosphate solubilization in bacteria isolated from alkaline soils. FEMS Microbiology Letter 182: 291-296.

Olsen SR, Dean LA (1965) Phosphorus 1. Methods of Soil Analysis. Part 2. Chemical and Microbiological Properties (1): 1035-1049.

Özkan N, Dağlığlu M, Ünser E, Müftüoğlu NM (2016) Vermikompostun spanak (Spinacia oleracea L.) verimi ve baz1 toprak özellikleri üzerine etkisi. Çanakkale Onsekiz Mart Üniversitesi Ziraat Fakültesi Dergisi 4(1): 1-5.

Papathanasiou F, Papadopoulos I, Tsakiris I, Tamoutsidis E (2012) Vermicompost as a soil supplement to improve growth, yield and quality of lettuce (Lactuca sativa L.). Journal of Food, Agriculture \& Environment 10(2): 677-682.
Parlak S, Güner D (2017) Mikrobiyal gübre uygulamasının karaçam (Pinus nigra Arnold. Subsp. Pallasiana (Lamb.) Holmboe) fidanlarının bazı morfolojik özelliklerine etkisi. Ormancılık Araştırma Dergisi 4(2): 100-106.

Pearson D, Churchill AA (1970) The chemical analyses of foods. Gloucester Place 104: 233.

Premuzic Z, Gárate A, Bonilla I (2002) Production of lettuce under different fertilisation treatments, yield and quality. Acta Horticulturae 571: 65-72.

Raupp J (1996) Fertilization effect on product qualiy and examination of parameters and methods for quality assessment. In: Roupp J. (Ed.), Quality of plant products grown with manure fertilization, Proceedings of the 1st Meeting Concerted Action Fertilization Systems in Organic Farming; Darmstadt, Germany, pp. 28-36.

Resmi Gazete (2008) Türk Gıda Kodeksi Yönetmeliği, Gıda Maddelerindeki Bulaşanların Maksimum Limitleri Hakkında Tebliğ (Tebliğ No: 2008/26) 17 Mayıs 2008, Say1: 26879.

Ricci M, Dos SF, Casali VWD, Cardoso AA, Ruiz HA (1995) Nutrient contents in two lettuce cultivars fertilised with organic compost. Pesquisa-Agropecuaria-Brasileira 30(8): 1035-1039.

Rodriguez H, Fraga R (1999) Phosphate solubilizing bacteria and their role in plant growth promotion. Biotechnology Advances 17: 319339.

Rosado AS, Seldin L (1993) Production of a Potentially Novel Antimicrobial Substance by Bacillus polymyxa. World Journal of Microbiology and Biotechnology 9(5): 521-528.

Ryu CM, Faraq MA, Hu CH, Reddy MS, Kloepper JW, Pare PW (2004) Bacterial volatiles induce systemic resistance in Arabidopsis. Plant Physiology 134: 1017-1026.

Shehata SM, Schmidhalter U, Valšíková M, Junge H (2016) Effect of bio-stimulants on yield and quality of head lettuce grown under two sources of nitrogen. Gesunde Pflanzen 68(1): 33-39.

Szwonek E (1986) Nitrates concentration in lettuce and spinach as dependent on nitrate doses. Acta Horticulturae 176: 93-97.

Üçok Z, Demir H, Sönmez İ, Polat E (2019) Farklı organik gübre uygulamalarının kıvırcık salatada (Lactuca sativa L. var. crispa) verim, kalite ve bitki besin elementi içeriklerine etkileri. Mediterranean Agricultural Sciences 32(özel say1): 63-68.

Vassilev N, Fenice M, Federici F (1996) Rock phosphate solubilization with gluconic acid produced by immobilized Penicillium variabile P16. Biotechnology Techniques 10: 585-588.

Vural H, Eşiyok D, Duman D (2000) Kültür Sebzeleri (Sebze Yetiştiriciliği). Ege Üniversitesi Ziraat Fakültesi Bahçe Bitkileri Bölümü, ISBN: 975-97190-0-2, Bornova, İzmir. 